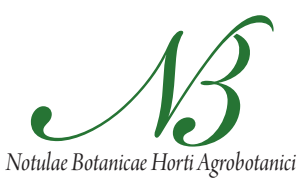

Cluj-Napoca

\title{
Impact of White Mistletoe (Viscum album ssp. abietis) Infection on Needles and Crown Morphology of Silver Fir (Abies alba Mill.)
}

\author{
Cătălina O. BARBU \\ "Ştefan cel Mare” University of Suceava, Faculty of Forestry, 13 Universității Street, Suceava, Romania; barbu_catalina2003@yahoo.com
}

\begin{abstract}
White mistletoe (Viscum album ssp. abietis (Wiesb.) Abromeit), (Santalales, Viscaceae) is a hemiparasite species and, in Romania, occurs only on silver fir (Abies alba Mill.). The species affects silver fir stands located mainly at lower elevations on the Eastern border of the silver fir natural distribution area. Along with drought and pollution, white mistletoe infection plays an important role in silver fir decline. The present study tried to quantify the mistletoe impact on crown degradation of silver fir trees, by measuring several parameters such as needle length and needle loss. The data were collected from a pure silver fir stand where more than $70 \%$ of trees were affected by mistletoe. The results indicate that both mistletoe infection and branch position into the crown influence the needles length. The reduction in needle length was more evident in the upper and middle part of the crown and smaller in the lower part of the crown, as well as in the "compensation crown" (formed by epicormic branches). The difference between needle lengths increases with the infection degree. In moderately and heavily infected trees, needles are falling in high proportion compared with low infected trees, demonstrating that mistletoe is producing crown degradation significantly reducing the photosynthetic tissue.
\end{abstract}

Keywords: crown degradation, needle length, needle loss, silver fir tree dieback

\section{Introduction}

White mistletoe (Viscum album ssp. abietis) is a hemiparasite species that depends on water and mineral nutrients provided by its host (Popp and Richter, 1998). It is one of the four subspecies of the European mistletoe parasitizing species of Abies (Zuber, 2004). The endophytic system of mistletoe consists of two parts: 1 ) the haustors or sinkers that reach the host cambium to absorb water, and 2) the cortical strands that provided lateral spread (Sallé, 1983).

In the last sixty years several scientists investigated silver fir infection with mistletoe across Europe: in France (Plagnat, 1950; Plagnat and Brossier, 1969), in Switzerland (Hofstetter, 1988; Noetzli et al., 2003), in Greece (Tsopelas et al., 2004), in Spain (Oliva and Colinas, 2007) and in Croatia (Idžojtić et al., 2008).

In Romania white mistletoe occurs only on silver fir (Abies alba Mill.) and is one of the most damaging pathogens that has affected silver fir stands (Barbu, 2009 b; Nanu, 1969). The decline of silver fir has long been reported in Romania and reached two peaks, in 1948 and 1966 (Brega, 1974; Giurgiu, 1969). The phenomenon has mainly developed after 1980, especially in the Suceava County, namely in Solca, Marginea, Mălini, and Gura Humorului forest districts, which are located on the northern part of Romanian Eastern Carpathians (Barbu, 1991; Bîndiu, 1996). The main causes of silver fir decline are: drought (Barbu, 1991, 1994, 1995; Geambaşu, 1988), pollution (Barbu, 1991; Bîndiu, 1996) and mistletoe
(Barbu and Barbu, 2005; Barbu, 2007, 2009 a, 2010 a, b; Nanu, 1969).

On the Eastern border of the natural distribution area, stands older than 100 years, especially those located at elevations lower than $600 \mathrm{~m}$, are more vulnerable to mistletoe since almost one fourth of the trees are infected (Barbu, $2010 \mathrm{a}$ ). The effects of mistletoes on their hosts consist of growth reductions, particularly height and diameter, as well as in vitality reduction, directly correlated with the degree of infestation. Furthermore any severe infection is frequently associated with premature dieback of host trees (Mathiasen et al., 2008; Peter - Contesse, 1937; Plagnat, 1950). As growth of the infected trees was subject to several previous studies (Barbu, 2009 a; Nanu, 1969; Noetzli et al., 2003), it is of interest whether white mistletoe infection is responsible for crown degradation of silver fir, since other genera of mistletoes, such as Archeutobium, seems to be responsible for a reduction of host's needle size (Logan et al., 2002; Reblin et al., 2006).

The aim of this study is to reveal the impact of mistletoe infection on crown morphology of silver fir, as function of infection degree.

\section{Materials and methods}

\section{Study site, field sampling and measurements}

The study was carried out in one square sample plot of one hectare (subsequently used for other measurements) placed in a damaged pure silver fir stand in Solca forest district (North part of Eastern Carpathians - Suceava county, 
Romania) where over $70 \%$ of trees are affected by mistletoe (Barbu, $2009 \mathrm{~b}$ ). The site ( $47^{\circ} 43^{\prime} \mathrm{N}$ and $\left.25^{\circ} 49^{\prime} \mathrm{E}\right)$ is situated at 520 meters a.s.l. on a north-east facing slope. The forest is dominated by 110 years old silver fir trees. Annual precipitation ranges between 740 and $800 \mathrm{~mm}$ and the mean annual temperature is $7.1^{\circ} \mathrm{C}$.

All trees within the sample plot were registered and measured for height and diameter at breast height (DBH). Social class - according to the Kraft classification (Kramer and Akca, 1987) was also determined. In addition, for each tree the degree of mistletoe infection was assessed using a four-class rating system developed for silver fir mistletoe (Fig. 1 and Tab. 1) (Barbu, 2009 a, b).

Further, in January 2009, 12 trees were selected (three tree of each infection class) and felled for detailed measurements. Sampled trees were selected according to the following criteria: pre-dominant and dominant (according to Kraft's classification), trees from the same class showing similar crown condition (estimated by crown transparency assessment), similar DBH and equal heights. All sampled trees had 10-12 meters length compensation crown formed by epicormic branches (Barbu, 1991, Čufar et al., 1995). It is worth to mention that $90 \%$ of the entire population of trees had produced such compensation crowns, between 10 and $14 \mathrm{~m}$ length.

To assess the influence of branch position on needle size and needle loss for each infection class a randomized branch sampling protocol was used. The normal crown of each felled tree was divided in three equal length sections (Barbu, 1991; Feller, 1992). To these three sections, a fourth section was added - the compensation crown. Two branches were randomly selected within each of these sections. From each selected branch, five shoots with 1 to 5 years old needles were randomly collected (Fig. 2 and 3). Needle length was assessed for 10 fresh needles of each sampled shoot and needle generation. For the measurements needles were separated and scanned with
Tab. 1. The four classes of infections used to quantify the presence and impact of mistletoe on silver fir trees

\begin{tabular}{cc}
\hline $\begin{array}{c}\text { Infection } \\
\text { class }\end{array}$ & Description \\
\hline Class 0 & No infection (healthy trees) \\
$1^{\text {st }}$ class & $\begin{array}{c}\text { Low infection, with frequent mistletoe shrubs on the } \\
\text { lateral branches of the upper part of the crown } \\
\text { Moderate infection, with very frequent mistletoe } \\
\text { shrubs in the crown, dried out branches and } \\
\text { moderate swellings along the branches }\end{array}$ \\
$2^{\text {nd }}$ class & $\begin{array}{c}\text { Heavy infection, with mistletoe shrubs all over the crown } \\
\text { and stem; heavy swellings along the branches and stem }\end{array}$ \\
$3^{\text {rd }}$ class
\end{tabular}

a distortion-free scanner (Flatbed Scanner Epson Expression $10000 \mathrm{XL}$ ). The images were imported in AutoCAD and needles were measured with a precision of $0.1 \mathrm{~mm}$. To assess the needle loss five shoots with needles formed in 1998-2008 period were randomly collected within each selected branch. Normally needles are maintained in the crown of the silver fir for 8-12 years (Barbu, 1991). Needle loss was evaluated by counting the number of needles generations per branch.

To assess the mistletoe effect in dry years we compared the mean annual needle length per infection class with precipitation (represented here by rainfall). Rainfall data (percent of multiannual rainfall average of late winter/ spring, i.e. February to April) for the nearest locality to the sample plot (i.e. Solca), were provided by the Forest Research and Management Planning Institute.

A total of 24,000 needles evenly distributed in the crown of sample trees were measured. After the needles were collected the same age needles were grouped in length classes for each section, infection class and sample tree.

\section{Statistical analyses}

The data collected from sample trees were tested for normality using Shapiro-Wilk test. One way ANOVA was
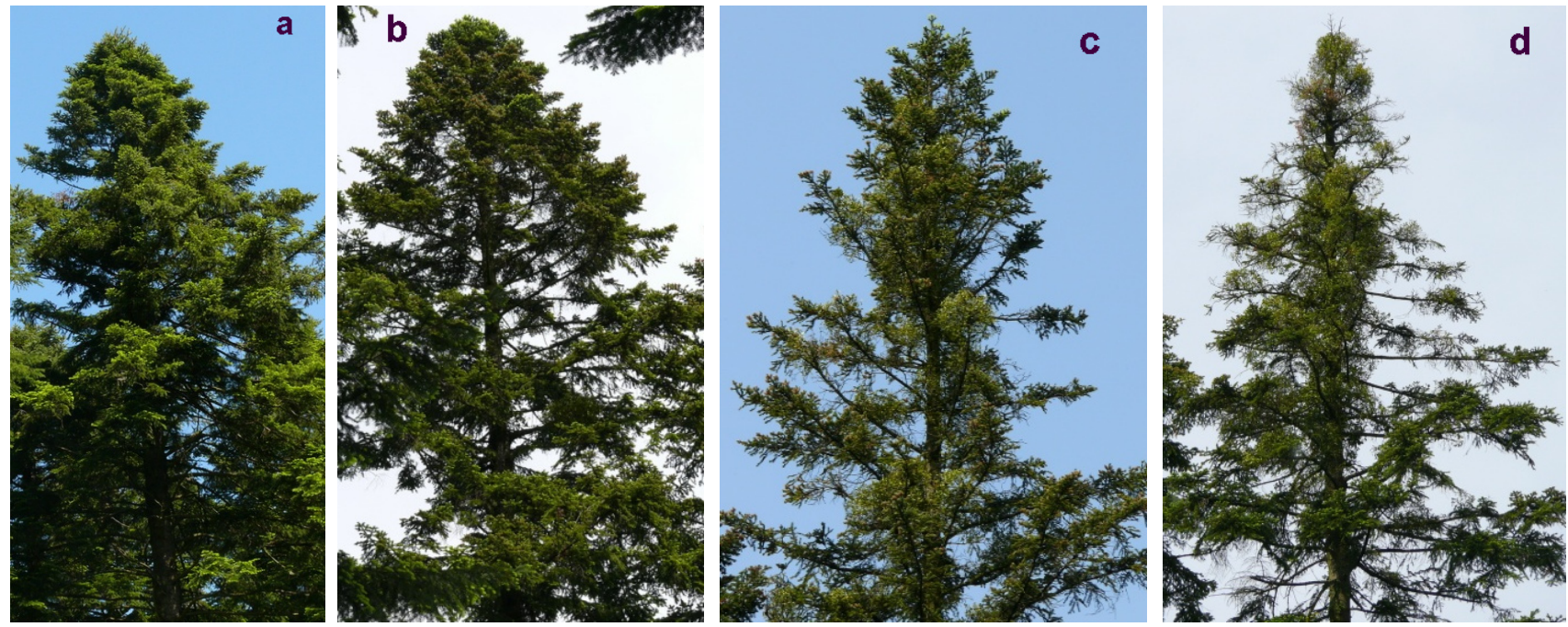

Fig. 1. Crown profile for trees of different mistletoe infection class:

a) Class 0 - healthy trees; b) $1^{\text {st }}$ class - low infection; c) $2^{\text {nd }}$ class - moderate infection, d) $3^{\text {rd }}$ class - heavy infection 
154

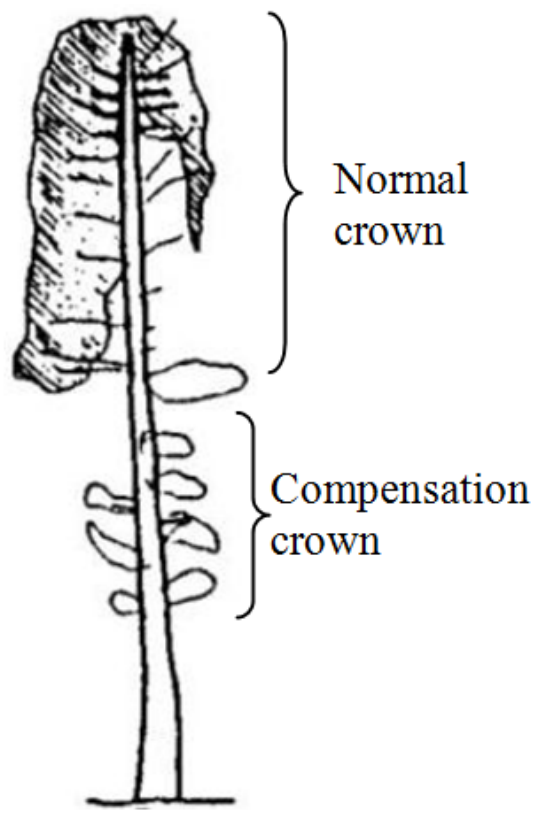

Fig. 2. Normal crown and compensation crown - formed by epicormic branches

used to assess the differences in needle length between infection classes, crown sections and year. The significance of differences between mean values was tested using the Tukey multiple comparisons tests (Zar, 2010). The significance level for all investigations was chosen $5 \%$, similar to
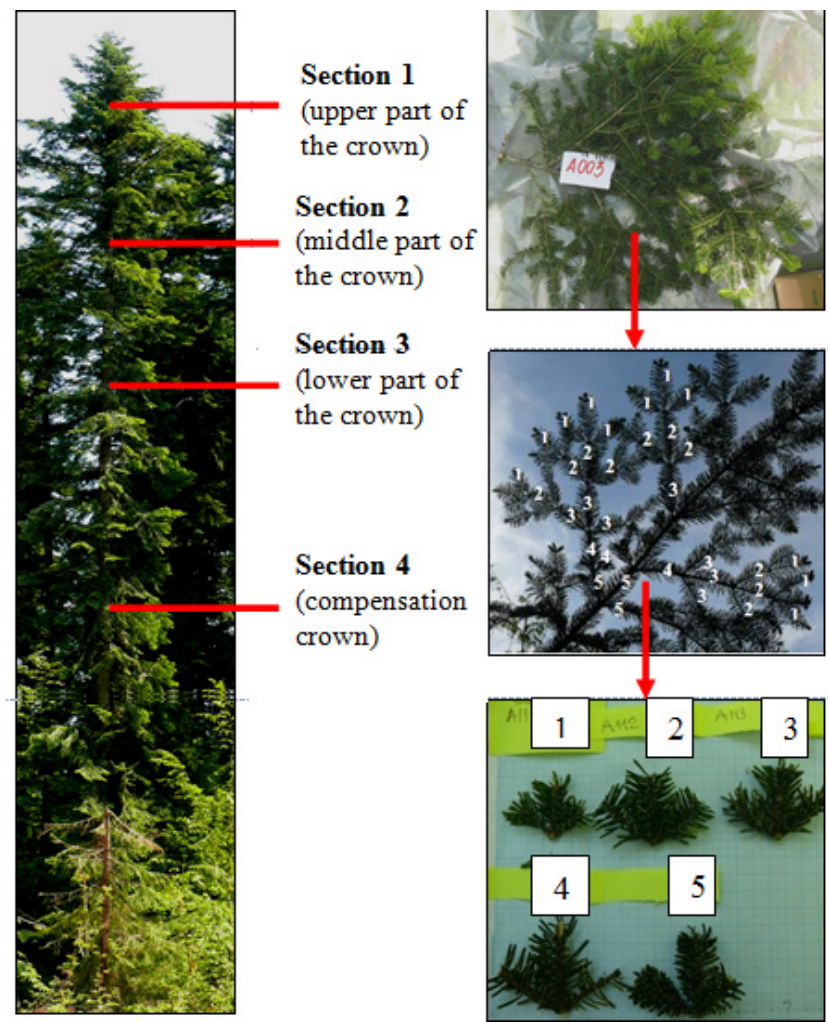

Fig. 3. Scheme of sampling (the numbers on the branch represent the needles age; 1 year old needles represent one generation, 2 years old needles represent - another generation, etc) the most of environmental studies $(\alpha=0.05)$ All statistical analyses were carried out by SAS software version. 9.1.3.

\section{Results}

ANOVA revealed significant differences $(p<0.0001)$ in needles length among sections, infection classes and needle ages (year). Significant interaction between section and infection class $(p<0.0001)$ was found. There were no significant differences between section and year $(p=0,92)$ and infection class and year $(p=0,64)$ (Tab. 2).

Tab. 2. ANOVA results concerning the effect of analyzed factors on needle length

\begin{tabular}{cccc}
\hline Source of variation & DF & F value & $\operatorname{Pr}>$ F \\
\hline Infection class & 3 & 679.281 & $<0,0001$ \\
Section & 3 & 1709.281 & $<0,0001$ \\
Year & 4 & 14.703 & $<0,0001$ \\
Section $\times$ Infection class & 9 & 50.170 & $<0,0001$ \\
Section $\times$ year & 12 & 0.491 & 0,921 \\
Infection class $\times$ Year & 12 & 0.83 & 0.647 \\
\hline
\end{tabular}

Mistletoe infection had a strong impact on needles size (Fig. 4) because the needles length of each infection class was significantly influenced by the branch position into the crown. The longest needles were found in healthy trees and the shortest ones in heavily infected trees.

In the upper part of the crown mistletoe infection led to a significant decline in needle lengths from one infection class to another; all differences between needles length are significant $(p<0.0001)$. In the middle and the lower part of the crown, needles length for healthy and low infected trees did not significantly differ $(p=0.937$, respectively

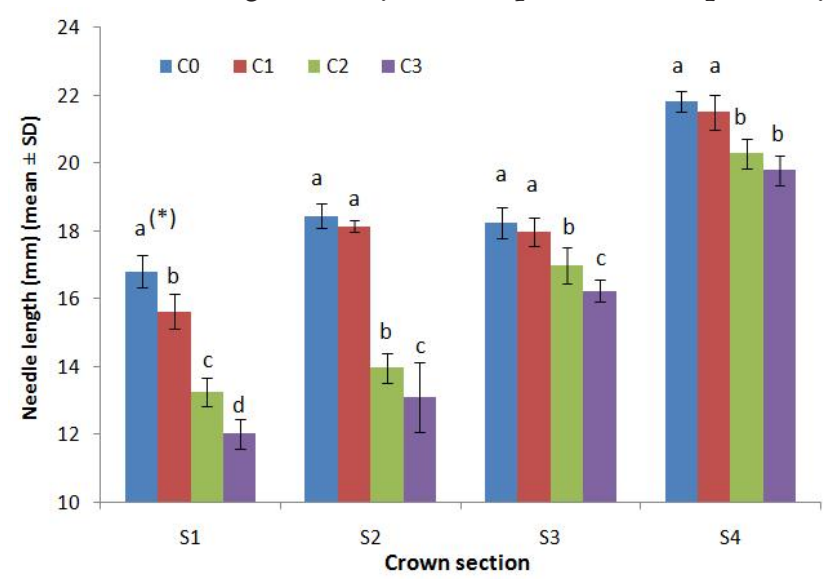

Fig. 4. Mean needle lengths according to the crown sections and infection class

Abbreviations: C0 - class 0 of infection, C1 - $1^{\text {st }}$ class of infection, C2 $-2^{\text {nd }}$ class of infection, C3 $-3^{\text {rd }}$ class of infection; S1 - section 1, S2 - section 2, S3 - section 3, S4 - section 4,

Note: The same superscript on columns denotes that the mean values do not differ significantly, $\left({ }^{*}\right)$ significance is valid at section level 


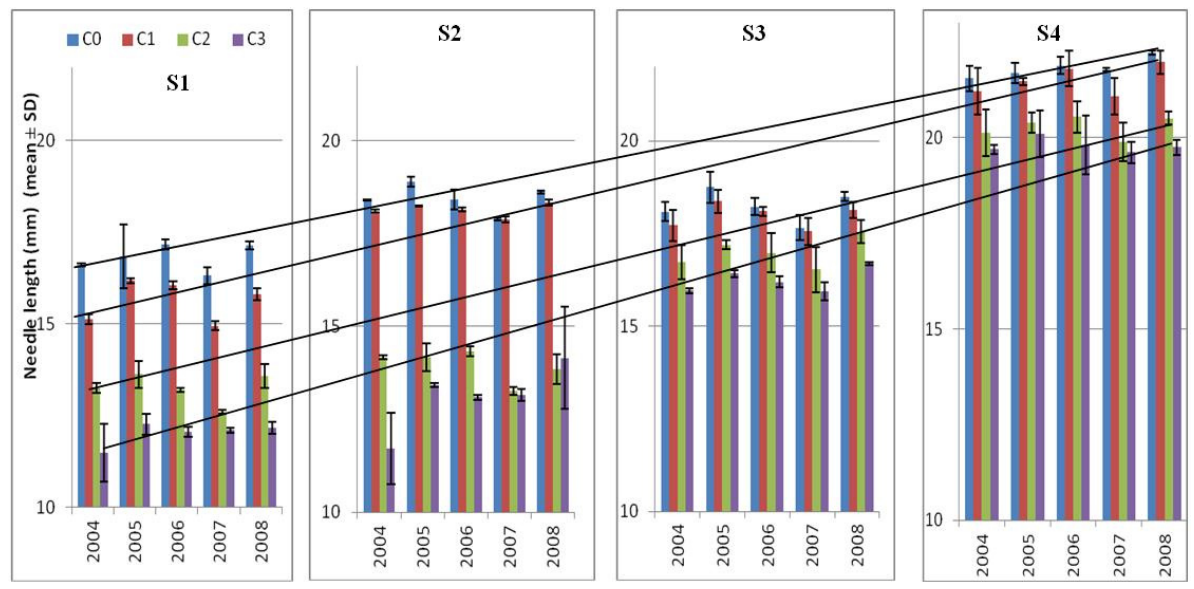

Fig. 5. Mean annual needle length on sections and infection classes. The lines represents the tendency to reduce needle length with the increasing of the infection degree at each section level

$p=0.981)$ but greater differences were found between these trees and moderate and heavy infected trees $(p<0.0001)$. In the compensation crown, in terms of needle length, the trees are split in two groups: 1 ) healthy and low infected trees and 2) moderate and heavy infected trees. Between these groups there are significant differences $(p<0.0001)$, but the reduction of needle length was lower than in the other sections.

Analyzing the needles on the whole crown, regardless the infection class, the smallest needles were found in the upper part and longest in the compensation crown.

The likelihood of finding shorter needles increases with the degree of infection (Fig. 5): the largest amplitude was found in the upper part of the crown, between healthy and heavy infected trees, while the lowest occurred in the compensation crown. Compared with healthy trees, for heavily infected trees the needles length of the upper and the middle thirds of the crown was diminished, on average, with 30-35\%, while in case of the lower part of the crown the reduction was smaller, between 10 and $12 \%$. In the compensation crown the reduction was $8-9 \%$ only. For moderate infected trees the needle length was reduced by $22-25 \%$ in the upper and middle part of the crown and by 7-8 \% in lower part and compensation crown. Low infected trees have been associated with the smallest reduction in needle length ( $7-8 \%$ in the upper part of the crown). For the other three sections the needle size reduction was insignificant.

In heavily infected trees the needles were falling in high proportions especially from the upper third of the crown. Forty percent fewer generations of needles were found in this section compared with healthy trees. In the other two sections (the middle and the lower thirds) thirty percent fewer generations of needles were found. In moderately infected trees, in all sections of the crown twenty percent fewer generations were found compared with healthy trees. For the low infected trees all generations of needles were found in the crown. In all cases, irrespective to the infection class, all generations of needles were found in the compensation crowns.

The rainfalls and the average needle lengths within infection classes went more or less correlated, as shown in Fig. 6; the needles were longer in rainy years and the average needle lengths of the four classes of infections are split into two distinctive groups: healthy and low infected trees, and moderate and heavy infected trees, respectively.

\section{Discussion}

The degrees of mistletoe infection is difficult to quantify. Many studies focused on mistletoe infections have been published (Dooling, 1978; Hawksworth, 1977), the 6-class system proposed by Hawksworth in 1977, designed for dwarf mistletoe being the standard rating system. For

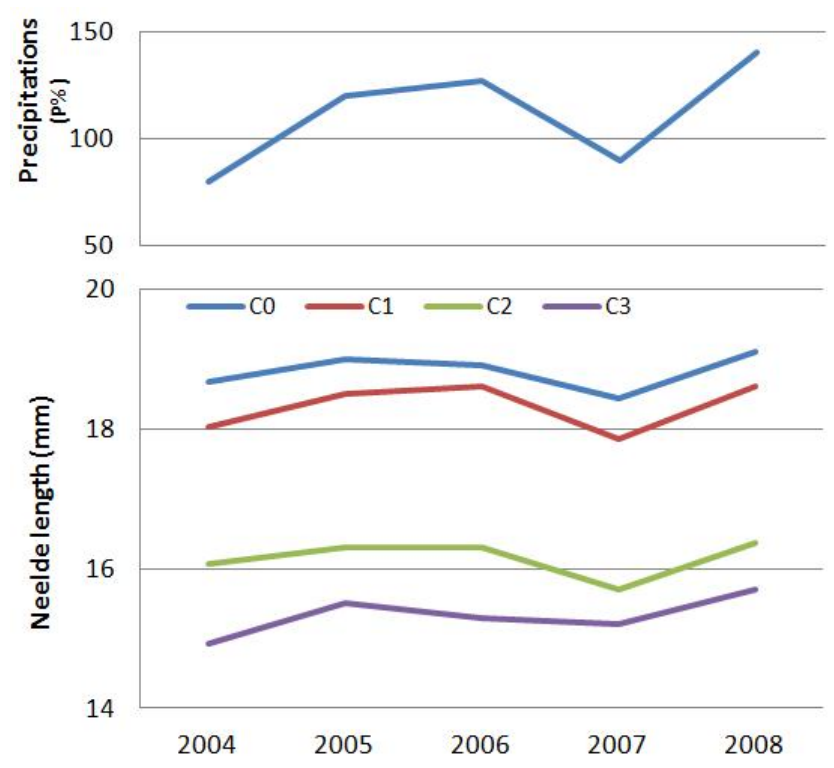

Fig. 6. Mean annual needle length related to February-April precipitations, separately for each infection class. Precipitations are presented as percentage of multiannual average of the period (P \%) 
156

quantifying the degree of infection the "4-class system" method developed for silver fir mistletoe was used (Barbu, 2009 a, b) in this study. Compared to the 6-class rating system which takes into consideration only the number of infected branches in each third of the crown, this method takes into account some other external symptoms of mistletoe infection, like: swelling and dieback of the branches, stem swelling and asymmetric crowns. Such indicators are important as, in many cases the mistletoe shrubs fall under the influence of snow or glazed frost (Barbu, 1991).

The natural vectors for mistletoe dispersal are birds. In the silver fir forests of Northern Carpathians, as in many other areas in Europe (Frochot and Salle, 1980), the main vector is mistletoe thrush (Turdus viscivorus L.). These birds are depositing the mistletoe seeds up in the canopy where, in the presence of light geminates and the plant grows up. In dense stands the mistletoe can develop only on higher trees (predominant and dominant) which receive enough light (Plagnat, 1950). It starts growing very slowly after infection with almost no impact on the host tree (see the $1^{\text {st }}$ class of infection), but after some years it grows exponentially (Noetzli et al., 2003) with negative consequences for the host tree (see $2^{\text {nd }}$ and $3^{\text {rd }}$ infection classes).

White mistletoe infection of silver fir is causing the crown degradation through a significant reduction in needle length and premature loss of needles. This is in line with the results of Rigling et al. (2010) for pine mistletoe (Viscum album ssp. austriacum) and Reblin et al. (2006) for dwarf mistletoe (Arceuthobium pusillum).

For the $1^{\text {st }}$ class of infection, when the parasite attacks only the branches, especially in the upper part of the crown (Barbu, 2009b), significant differences were found between needle sizes, compared with healthy trees (class 0 ), only in this part of the crown. Elsewhere in the crown there were no differences in needle size, compared with the healthy trees. For the trees of the $2^{\text {nd }}$ class of infection where the mistletoe shrubs are more frequent, and the mistletoe sinkers have reached the insertion of branches onto the stem, the needle size for all sections of the crown differs significantly. When comparing the $3^{\text {rd }}$ class of infection with the $2^{\text {nd }}$ class, it was found that the mistletoe infection is damaging not only the crown, but also the stem; actually, cohorts of mistletoe sinkers were observed at stem level in the upper and middle part of the crown after felling the trees, causing numerous swellings in the sinkers areas. The needles of trees from $3^{\text {rd }}$ class were significantly smaller than needles of the trees belonging to other infection classes, irrespective to the crown section.

In general, in the lower part of the crown (section three) the mistletoe occurs due to a vertical reinfection (Barbu, 1991). From the mature shrubs stuck in the upper part of the crown, mistletoe seeds fall and adhere, due to the viscin layer (Frochot and Sallé, 1980), on the branches of the lower part where, with a sufficient amount of light, mistletoe shrubs develop, the age of infection being lower. This might be the reason why in this section the reduction in needle size was not so important.
For the needles of the upper part of the crown for pine mistletoe infection Rigling et al. (2010) found that needle length was reduced by $27 \%$. In this case the percentage reduction in needle size of the upper third of the crown was four times greater for the $3^{\text {rd }}$ class of infection that for $1^{\text {st }}$ class (30-35\% compared with 7-8\%) compared with healthy trees. In the infected trees, in relation to the degree of infection, $20-40 \%$ fewer generations of needles were found. This result confirms the findings of Rigling $e t$ al. (2010) for Viscum album ssp. austriacum where thirty percent fewer needle generations of infected trees were reported.

Compared with its host trees, the mistletoe has a higher rate of transpiration and lower leaf water potential (Popp and Richter, 1998). Consequently the xylem conductivity distal to the infection point can be reduced, areas situated above the attack being poorly supplied with water (Ehleringer et al., 1985). Mistletoe "is starving and dehydrating the host" (Plagnat, 1950). This leads to a premature loss of needles and, by the end, to the dieback of affected branches (Mathiasen et al., 2008). The needle size reduction in relation to infection degree and position in the crown might be a result of an increasing water stress due to mistletoe infection. On the other hand, according to Ehleringer et al. (1985), Marshall and Ehleringer (1990), Escher et al. (2004) xylem parasites and in particular mistletoe species are highly dependent on the supply of organic carbon and nitrogen from their hosts, shrinking the leaf area. Reduction in needle size could be a response to mistletoe infection, because smaller needles would require lower amounts of nitrogen and fixed carbon (Reblin et al., 2006).

Needle length depends on water availability in the late winter and spring (i.e. February to April), the length variations within a year being related to the corresponding rainfall. In all years included in the study the percentage of multiannual average precipitation ranges between 80 and $145 \%$, corresponding to a normal regime of rainfall within the studied area (Barbu and Popa, 2003).

Often, the crown of the trees that are dying form on the trunk compensation crowns (formed by epicormic branches). These compensation crowns have been formed in the last 15-20 years (Barbu and Barbu, 2005). This is the reason why, in determining the needle length, we considered the compensation crown as the fourth section. Epicormic branches formation - known also as "agony branches"- is often associated with the thinning of stand followed by a sudden exposure of trees to light takes places. (Čufar et al., 1995; Niccolini et al., 2001). Bruner (1964) considered that trees with epicormic branches are "suppressed" trees, with reduced cambial activity; the formation of these branches does not depend on stand thinning, but sudden changes in the environment only emphasizes this effect. Field observations, made in infected silver fir stands, revealed that mistletoe did not occur on branches of the compensation crown. In this case, after felling the 
12 sampled trees no mistletoe bushes were found in the compensation crown.

Some silvicultural works in silver fir stands affected by mistletoe are recommended, after a careful analysis of each stand. In pure silver fir stand, as it was the case in this study, where the frequency of infected trees exceeds 70 $80 \%$, all affected trees are to be harvested (Barbu, 2009 b). In uneven aged stands, where silver fir trees are numerous and infected here and there, the stand composition shall be steered to a lower proportion of silver fir, by promoting mixed stands. Further research have to be done in order to determine that the mistletoe infection make infected trees crown susceptible to additional stress factors.

\section{Conclusions}

The results showed, in a representative stand of silver fir, that mistletoe infection conveyed by a reduction of needle length and a premature needle shedding had a negative impact on the crown of the host tree. The needles size and needle loss were significantly influenced by the infection class and the branch position in the crown showing that white mistletoe negative influence on the crown of its host is increasing along with the infection degree.

\section{References}

Barbu C (2007). Aspects regarding mistletoe (Viscum album ssp. abietis) infection symptoms in Silver fir stands. Lucrările sesiunii ştiințifice „Pădurea şi dezvoltarea durabilă”, Ed Universității Transilvania Braşov, p. 183-189.

Barbu C (2009 a). Impact of mistletoe attack (Viscum album ssp. abietis) on radial growth of Silver fir. A case study in the North of Eastern Carpathians. Ann Forest Res 52(1):8996.

Barbu C (2009 b). Ecophysiological researches in silver fir stands of Obcinele Bucovinei, infected by mistletoe. PhD Thesis. Universitatea "Transilvania" din Braşov. Facultatea de Silvicultură și Exploatări Forestiere, 223 p. (in Romanian).

Barbu C (2010 a). The incidence and distribution of white mistletoe (Viscum album ssp. abietis) on Silver fir (Abies alba Mill.) stands from Eastern Carpathians. Ann Forest Res 53(1):27-36.

Barbu C (2010 b). Silver fir stands infected by mistletoe (Viscum album ssp. abietis) dynamics in the context of climate change. Lucrări științifice, seria Horticultură 53(1):609-615.

Barbu I (1991). Silver fir dieback. A symptom of the environment degradation. Ed Ceres, Bucureşti, 276 p. (in Romanian).

Barbu I (1994). Contribution to the knowledge of the ecological conditions in areas damaged by Silver fir dieback in Bukovina, Bucovina Forestieră 2:5-11 (in Romanian).

Barbu I (1995). Tannensterben in Rumanien, In: Ergebnisse des 7 IUFRO Tannen symposium. Mainz, Germany: 227-238 p.
Barbu I, Popa I (2003). Drought Monitoring in the forests of Romania. Ed. Tehnică Silvică, Bucureşti, 128 p. (in Romanian).

Barbu I, Barbu C (2005). Silver fir in Romania. Ed. Tehnică Silvică, Bucureşti, $220 \mathrm{p}$.

Bîndiu C (1996). Forest decline, a phenomenon with deep ecological impacts. Revista Pădurilor 3:38-43. (in Romanian).

Brega P (1974). Siver fir issue in Suceava county. Revista Pădurilor 7:356-362. (in Romanian)

Bruner MH (1964). Epicormic sprouting on released YellowPoplar. Forestry 62:754-755.

Čufar K, Robič D, Torelli N, Kermavnar A (1995). Phenology, occurrence of epicormic branches and reproductive growth on air-polluted silver firs. Acta pharm (Zagreb) 45(2):379381.

Dooling OJ (1978). Survey methods to determine the distribution and intensity of dwarf mistletoes. Proc. Sympos. Dwarf Mistletoe Control For. Manag. U.S. Dep Agric For Serv Gen Tech Rep PSW 31:36-44.

Ehleringer JR, Schulze ED, Ziegler H, Lange OL, Farquhar GD, Cowar IR (1985). Xilem - tapping mistletoes: water or nutrient parasites. Science 227:1479-1481.

Escher P, Eiblmeier M, Hetzger I, Rennenberg H (2004). Spatial and seasonal variation of carbohydrates in mistletoes (Viscum album) and the xilem of its hosts (Populus $\times$ euramericana and Abies alba). Physiol Plant 120:212-219.

Feller MC (1992). Generalized versus site-specific biomass regression equations for Pseudotsuga menziesii var menziesii and Thuja plicata in costal British-Columbia. Bioresurce Technology 39:9-16.

Frochot H, Salle G (1980). Modalités de dissémination et d'implantation du gui. Rev Forestière Fr 32:505-519.

Geambaşu N (1988). Drought and silver fir die-back in some forests of Bukovina. Revista pădurilor 2:72-80. (in Romanian).

Giurgiu V (1969). Silver fir issue in Romania. Revista pădurilor 7:328-332. (in Romanian).

Hawksworth FG (1977). The 6-class dwarf mistletoe rating system. General Technical Report RM-48. Fort Collins, CO: U.S. Department of Agriculture, Forest Service, Rocky Mountain Forest and Range Experiment Station, 7 p.

Hofstetter M (1988). Über die Verbreitung der Mistel in der Schweiz. Schweitz. Z Forstwes 139:97-127.

Idžojtić M, Pernar RM, Glavaš M, Zebec M, Diminić D (2008). The incidence of mistletoe (Viscum album ssp. abietis) on silver fir (Abies alba) in Croația. Biologia 63(1):81-85.

Kramer H, Akca A (1987). Leitfaden füf Dendrometrie und Bestandesinventur, Sauerlander, Frankfurt am Main.

Logan BA, Huhn ER, Tissue DT (2002). Photosynthetic characteristics of eastern dwarf mistletoe (Arceuthobium pusillum Peck) and its effecs on the needles of host white spuce (Picea glauca (Moench) Voss). Plant Biol 4:213-220. 
158

Mathiasen RL, Nickrent DL, Shaw DC, Watson DM (2008). Mistletoes: pathology, systematics, ecology and management. Plant Dis 92:988-1006.

Marshall JD, EhleringerJR (1990). Are xylem-tapping mistletoes partially heterotrophic? Oecologia 84:244-248.

Nanu N (1969). Mistletoe (Viscum album L.) - a parasite of Silver fir stands from Anina - Oravița calcareous Plateau. Revista pădurilor 4:177-178. (in Romanian).

Niccolini E, Chanson B, Bonne F (2001). Stem growth and epicormic branch formation in understory beech trees (Fagus sylvatica L.). Ann Bot 87:737-750.

Noetzli KP, Müller B, Sieber TN (2003). Impact of population dynamics of white mistletoe (Viscum album subsp. abietis) on European silver fir (Abies alba). Ann Sci 60:773-779.

Oliva J, Colinas C (2007). Decline of Silver fir (Abies alba Mill.) stands in the Spanish Pyrenees: Role of management, historic dynamics and pathogens. Forest Ecol Manag 252:84-97.

Peter-Contesse J (1937). Influence de gui sur la production de bois de service. J forest suisse 7:145-153.

Plagnat F (1950). Le gui du sapin. Annales de l'École nationale des eaux et Forêts, tome XII:155-231.

Plagnat F, Brossier J (1969). Les sapiniares a gui. Rev Forestière Fr. 6:553-557.
Popp M, Richter A (1998). Ecophysiology of xylem-tapping mistletoes. Prog Bot 59:659-672.

Reblin JS, Logan BA, Tissue DT (2006). Impact of eastern dwarf mistletoe (Arceuthobium pusillum) infections on the needles of red spruce (Picea pungens) and white spruce (Picea glauca): oxygen exchange, morphology and composition. Tree Physiology 26:1325-1332.

Rigling A, Eilmann R, Koechli R, Dobbertin M (2010). Mistletoe-induced crown degradation in Scots pine in a xeric environment. Tree Physiology 30:845-852.

Sallé G (1983). Germination and establishment of Viscum album L., 154-159 p. In: Calder M, Bernhard P (Eds.). The biology of mistletoes. Acad Pr Sydney

Tsopelas P, Angelopoulos A, Economou A, Soulioti N (2004). Mistletoe (Viscum album) in the fir forest of Mount Parnis, Greece. Forest Ecol Manag 202:59-65.

Zar JH (2010). Biostatistical Analysis - $5^{\text {th }}$ edition. Pearson Prentice Hall, New Jersey, USA, 944 p.

Zuber D (2004). Biological flora of Central Europe: Viscum album L. Flora 199:181-203. 